\title{
Secondary schools' administration perspective on content and language integrated learning: the case of Lithuania
}

\author{
Loreta Andziuliené*, Daiva Verikaitè-Gaigaliené** \\ *Education Academy, Vytautas Magnus University, Vilnius, Lithuania; loreta.andziuliene@vdu.It \\ **Education Academy, Vytautas Magnus University, Vilnius, Lithuania; daiva.verikaite-gaigaliene@vdu.It
}

\begin{abstract}
The aim of the present study is to investigate the present state and existing models of Content and Language Integrated Learning (CLIL) in the monolingual context of Lithuania and the current perspective of school administrators (school principals and vice-principals) on CLIL and its implementation in Lithuanian secondary schools. A survey of three hundred and one school administrators was conducted. The article discusses the results of the survey by considering the present state of CLIL in Lithuanian secondary schools, the factors that would motivate school administrators to be more willing to engage in CLIL implementation, and the help that school administrators perceive as necessary for more efficient CLIL implementation in their schools. The results of the present study are intended to provide suggestions and recommendations for using CLIL more effectively in Lithuanian secondary school classrooms.
\end{abstract}

Keywords: CLIL, bilingual education, secondary schools, school administrators, survey

\section{Introduction}

Content and Language Integrated Learning (CLIL) as "a dual-focused educational approach in which an additional language is used for the learning and teaching of both content and language" (Coyle et al. 2010: 1) emerged as a concept in Europe in the early 1990s and has expanded throughout the countries of Asia, Latin America and Europe (Pérez Cañado 2018). CLIL involves teaching or learning a non-language subject "with and through a foreign language" or a regional/minority or state language (Eurydice 2006, 2017), or using a foreign language as a tool to improve foreign-language skills (Lo 2014) rather than teaching or learning in a foreign language, e.g. English, which is single-focused while learning a particular subject and, thus is considered as English Medium Instruction (EMI) (Pérez et al. 2018). There is no data showing the expansion of CLIL programmes in the European Union (EU), but it may be assumed that "only in a handful of countries is CLIL provision available in all schools at some stage of education" (Eurydice 2017: 13). The problem with obtaining globally comparable data as to the provision of this type of bilingual education might be caused by the variety of CLIL modes adopted by schools or education governing bodies in different countries.

CLIL is an umbrella term for various educational approaches such as bilingual education, multilingual education, and immersion where the latter is classified into partial, total, two-way or double according to the degree of exposure to a foreign language (Mehisto et al. 2012, Mehisto 2014). However, not all researchers support such a flexible interpretation of this approach, and some argue that CLIL and immersion modes bear significant differences and cannot be perceived as the same approach (Sylvén and Thompson 2015). There is no question, however, that CLIL manifests itself in a variety of forms, pedagogies and practices (García 2009) and "whether a concrete program is referred to as immersion or CLIL often depends as much on its cultural and political frame of reference as on the actual characteristics of the program" (Dalton-Puffer 2011: 183). Different national education policies and cultures dictate the variations in bilingual education; nonetheless the main principles are in line with the EU policies mentioned in significant declarations (European Commission 1995, 2003, 2008).

Typical CLIL practice, as described by Dalton-Puffer (2011), takes place when a foreign language used in a CLIL class is not normally used outside the classroom; CLIL teachers are mainly subject teachers who are usually neither foreign-language specialists nor native speakers, and less than $50 \%$ of the curriculum is covered in a foreign language. CLIL programmes usually encompassing some non-linguistic subject lessons or series of lessons that might occupy practically all the available hours for the subject throughout a year or longer are termed "hard" CLIL programmes, whereas "soft" CLIL usually means shorter programme arrangements where part of the subject curriculum is selected for teaching through a foreign language and 
very often involves the participation of a foreign-language teacher who increases the value of foreignlanguage learning (Ball et al. 2015).

The organisation and intensity of CLIL programmes are closely related with a school's vision and mission, and at the same time are dependent on the readiness of personnel and learners to become involved in such programmes. In Europe, therefore, considerable flexibility exists in terms of the provision of CLIL programmes in secondary schools, since communities in different countries may differ substantially and a model that is effective in one country might not be effective in another (Pérez et al. 2018). In Austria, for example, CLIL initiatives are sanctioned at all educational levels and types of school, and as neither the CLIL curriculum, nor learning outcomes, nor quantity or quality of the CLIL provision are specified in any requisite document, it is within a school's competence to choose the kind and extent of CLIL to apply (Hüttner et al. 2013). In Lithuania, education policy makers attempt to respect the national situation and suggest three possible models of CLIL, i.e. project level, school level and national level (Dalyko ir užsienio kalbos integruoto mokymo(si) gairès (Content and Language Integrated Learning Guidelines) 2010). This recommendation is based on the organisation and intensity of CLIL that learners are exposed to, while CLIL curricular models in Poland, where teacher training policy is similar to that in Lithuania, are categorised according to the amount of a foreign language used in a class (Czura and Papaja 2013). Three models of CLIL can be found in lower secondary schools, i.e. Extensive Language Medium Instruction when the classes are given mainly in a foreign language, Partial Language Medium Instruction when both state and foreign languages are used in a class, and Limited Language Medium Instruction when 10-50\% of a foreign language is used to conduct a class (Romanowski 2018).

The degree to which a foreign language is used in a CLIL class is often interrelated with the teacher's qualification, i.e. the subject teacher's command of a foreign language that would satisfy the minimum requirements to teach both a subject and a foreign language. This issue is acute in countries where teachers major in only one subject as in Lithuania, where an attempt to start preparing potential CLIL teachers within the framework of the History and English Pedagogy study programme at the Lithuanian University of Educational Sciences (Andziuliene 2016) failed, and Lithuanian teachers are still trained to deliver either a subject or a language. Consequently, a co-teaching mode is an option in cases where subject teachers need assistance with a foreign language in class. School administrations encourage crosscurricular collaboration even if subject teachers have sufficient knowledge of a foreign language. This is the case in the Netherlands where teachers need to demonstrate at least B2 level according to Common European Framework of Reference (CEFR) (Council of Europe 2001, 2018, Standard for Bilingual Education 2012). Moreover, in order for a school to implement CLIL in the Netherlands, teachers need to meet another pre-requisite requirement, i.e. to have had some training in CLIL methodology (ibid.).

To conclude, in order to ensure the quality of CLIL education, the responsibility should be delegated either to local accreditation boards, if such exist, or to other education authorities as well as to the school management, all of which are considered to be the most decisive institutional bodies. This can be strengthened by sustainable collaboration among all the stakeholders involved in the process.

\section{Prior research on the administration perspective on CLIL}

The majority of previous studies on CLIL centre on the outcomes and effects of CLIL (Dalton-Puffer 2011, Pérez-Cañado 2012), whereas the number of studies on school administrations and their perspective on CLIL is insignificant (Doiz and Lasagabaster 2017). Though school internal stakeholders such as principals, vice-principals and department heads are key figures both in decision making and communicating their vision to other internal and external stakeholders, who in their turn, might be cautious about or even resistant to such innovations as CLIL, there is a lack of empirical research on the perspective of CLIL programme participants (Hüttner et al. 2013). The perception of CLIL by different stakeholder groups has been researched quite thoroughly (Codó and Patiño-Santos 2017), but in most cases the focus is placed mainly on student beliefs and opinions, and some attention is devoted to teachers and parents, whereas "management teams have remained mostly invisible" (Doiz and Lasagabaster 2017: 94).

The opinion of school administrations, however, can be retrieved from smaller or larger-scale research projects on CLIL carried out in Europe and beyond. Addressing the comparative-study gap as regards 
teacher and administration beliefs about CLIL, Doiz and Lasagabaster (2017) conducted a longitudinal research in three public schools based in a bilingual Basque Community, and discovered that CLIL programme management teams from the three schools applied different strategies to solve complex issues and often needed to experiment when encountering difficulties applying CLIL in their schools. The findings report that teachers and administration reach consensus speaking of CLIL implementation, though they do not necessarily share their views at every stage. Moreover, the administration support for teachers cannot be undervalued as teachers might refuse to participate in CLIL programmes requiring more time, effort, specific knowledge and additional skills.

Estonia considers stakeholder opinion crucial in launching sustainable CLIL at all levels of education (Lancaster 2016) as "ultimately stakeholder relationships make or break any new programme" (Mehisto and Genesee 2015: 272). Understanding the crucial role of administration, Mehisto and Asser (2007) conducted a qualitative study on stakeholder perspectives, giving proper attention to school principals' and vice-principals' perspectives on CLIL programme management. The findings report that representatives of school administrations understand the significance of their roles and take responsibility for successful and sustainable CLIL implementation. This requires not only being aware of CLIL principles and having managerial skills but also involves understanding other stakeholders' attitudes and beliefs as well as maintaining close collaboration with them. Moreover, professional development for school principals and vice-principals is emphasised as an essential factor since, even having undergone the necessary training, school principals were not confidant enough in launching CLIL programmes.

Another study that aimed to investigate successful CLIL implementation from the leadership perspective was in Catalonia (Soler et al. 2017). The results disclosed school principals' and other stakeholders' perception of beneficial CLIL practice. All stakeholders believed that CLIL programmes could be beneficial if the main criteria are met, criteria such as a clearly structured programme, CLIL teacher competences and professional development in terms of language and methodology, cooperative work, management support, and sufficient and constant exposure of learners to the language being learnt. It is within a school administration's responsibility to ensure well-thought out and slow implementation of CLIL programmes, as well as to advocate for CLIL, support teachers and encourage teacher collaboration and professional learning.

In Spain, another recent study by Codó and Patiño-Santos (2017) employed an ethnographic perspective to a case in one state school and aimed to investigate the Catalan government's initiative to implement a Plurilingual Experimentation Plan (PEP), a designed model of CLIL implementation for all levels and types of schools. The study revealed different perceptions towards the programme from the perspectives of the various agents involved, including administrators. As far as school leadership is concerned, the study showed that PEP influences the school administration's mind set and management strategies. Having a considerable amount of school autonomy, school principals look for the possibilities for their schools to differ from other schools in order to be attractive in this "highly competitive educational arena" (Codó and Patiño-Santos 2017: 494). The latter study was conducted in the context where learning foreign languages, especially English, is fostered by another stakeholder group - parents, who have expectations for their children to work in the global market (Codó and Patiño-Santos 2017).

A different situation is encountered in Australia, where learning foreign languages is not seen as having any priority; nevertheless CLIL is offered in some schools (Smala 2014). Smala (2014) conducted a study in the Australian state of Queensland and examined the point of view of CLIL programme directors on CLIL. As CLIL programmes exist separately, without any guiding support from some higher governing body, CLIL programme directors need to perform roles that normally are beyond the administrator's duties, i.e. not only to lead teachers, but to work intensely with other stakeholders in order to show the value of CLIL, to attract students to the programmes, to deal with the necessary curriculum requirements for teaching a subject through a foreign language, and to foster teacher collaboration. CLIL programme directors believe that systematic CLIL teacher education would contribute to more effective management of CLIL programmes.

In Lithuania, an attempt to investigate the school administration's perspective on CLIL was made by Bijeikienè and Pundziuvienè (2015). Their case study at Didždvaris gymnasium aimed at examining 
stakeholders' attitudes towards CLIL; however, it cannot be perceived as representing the whole population of secondary school administration in Lithuania.

\section{Justification for the research}

In the context of this state of affairs, it becomes highly relevant to investigate the current situation of CLIL in Lithuanian secondary schools by shedding some light on the perspective that stakeholders (administration, teachers and students) have toward CLIL and its implementation. Due to the restricted scope of this article, the decision was made to limit the investigation to the school administration perspective (school principals and vice-principals) especially since the 2006 survey of school CLIL teachers in Lithuania demonstrated that the school administration perspective (lack of support) was one of the three main factors hindering the implementation of CLIL (Andziulienè et al. 2007) and that the role of a principal as the instructional / curriculum leader is crucial since "a principal sets the tone for a school and ultimately takes responsibility for what is taught and how it is taught $<\ldots . .>$ [as well as] sets an example for others and dictates to a considerable extent the focus of professional dialogue in the school" (Mehisto 2014: 44).

Therefore, the aim of the present article was to investigate the current perspective of school administrators (school principals and vice-principals) on CLIL and its implementation in Lithuanian secondary schools. The objectives of the article were:

(1) To analyse the shape of CLIL provision in Lithuanian secondary schools.

(2) To determine the factors motivating a school administration to become engaged in CLIL implementation.

(3) To compare the school administration perspective in schools engaged in CLIL implementation with the perspective of school administrators in schools that have not yet been engaged in CLIL implementation.

To achieve the aim and the objectives of this study, the following research procedure was followed:

(1) A questionnaire was designed as the principal survey tool.

(2) A survey of three hundred and one school administrators selected randomly was conducted.

(3) The quantitative data were processed using an SPSS software package.

The research methods used were analysis of documents and survey results. The current research was carried out in order to identify the implications for, and recommendations on, a more effective use of CLIL in Lithuanian secondary school classrooms.

\section{Methodology}

A survey was used as the main research method in the present study. It examined a representative sample of the school population and covered three hundred and one schools represented by school administrators selected randomly. The questionnaire was designed and used as the principal tool for the survey.

\section{Sampling}

The research population ( $n=282$ ) was calculated using the online sample size calculator Raosoft (http://www.raosoft.com/samplesize.html). According to the Education management information system (http://svis.emokykla.It), in Lithuania there were 1,151 schools of secondary education in the academic year 2016/2017. With the exclusion of secondary education institutions such as specialized schools, socializing centres, adult schools and international schools, our representative sample comprised 301 schools, i.e. $28.6 \%$ of the 1,054 overall school population.

In order to ensure the reliability of the research results, the survey covered schools representing all municipalities in Lithuania - both in urban and rural areas, schools with Lithuanian, Polish, and Russian language of instruction, and schools representing all levels of secondary education. A random selection method was used to address every third school on the list in alphabetical order. 


\section{Research instrument and data collection}

The questionnaire, designed to be the main source of the data, was piloted with school principals or vice-principals in one municipality. The questionnaire consisted of three parts; however, this study is based on the first two parts that were related to the research question of the present study. The first part was intended to determine the current state of CLIL provision in Lithuanian secondary schools in terms of the number of schools implementing CLIL, the forms of CLIL, the most popular CLIL subjects, the initiators of CLIL, and the grades in which CLIL is provided most recurrently. The second part with a 5-point Likert scale ( 1 expressing strong disagreement and 5 expressing strong agreement with the given statement) included questions helping to define the school administration perspective on the importance of CLIL, the school community's awareness of CLIL, teachers' professional qualifications for teaching CLIL and the need for their improvement, principals' inclination towards the introduction of CLIL into school curriculum, towards the support of teachers' professional development, and towards finding resources for paying CLIL teachers. An open-ended question was included to elicit the personal opinion and recommendations of school principals for more effective CLIL implementation in Lithuanian secondary schools.

To ensure the selection of an appropriate target group of respondents, i.e. school principals or viceprincipals for studies, prior phone calls were placed and agreement to complete the questionnaire was received. A total of 490 questionnaires were sent personally to school principals or vice-principals and 301 questionnaires were returned and were used for further analysis. The Cronbach $\alpha$ assessment of the reliability of the questionnaire was 0.84 .

\section{Data analysis}

Quantitative data were processed using the SSPS software package. For the comparison of two groups of the respondents - those from schools with CLIL and those from schools without CLIL - a Pearson ChiSquare test was applied. Descriptive statistics were used for further analysis exploring the attitudes of each respondent group towards CLIL implementation.

\section{Results}

The results are subdivided into two parts: the first part presents the current situation of CLIL in Lithuanian secondary schools and the second part provides insights into the perspective of the school administration (principals and vice-principals for studies).

\section{CLIL in Lithuanian secondary schools}

The survey results revealed that nearly half of the schools surveyed implement CLIL to a certain degree. However, the majority of the schools that do not presently implement CLIL have no intention of implementing it in the future (see Figure 1).

Figure 1: CLIL in Lithuanian secondary schools.

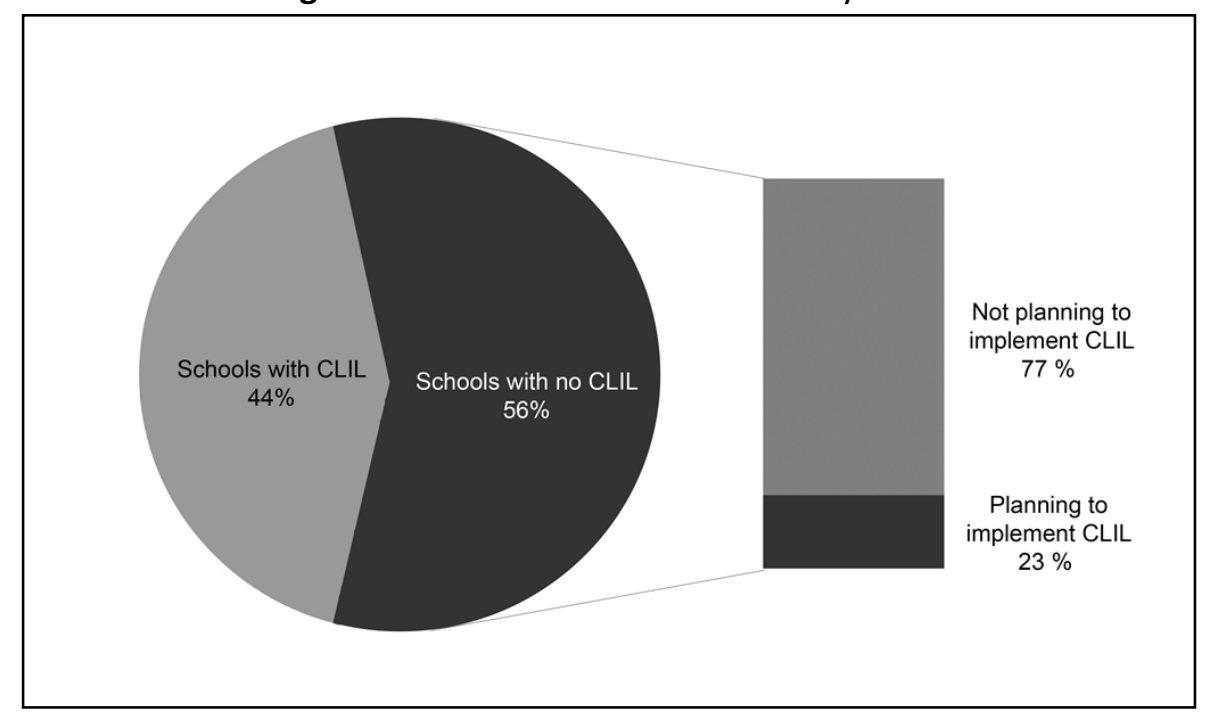


As concerns the most popular forms of CLIL implementation in the schools surveyed, the integration of CLIL in either foreign-language classes or subject classes by far surpasses other forms of CLIL such as a supplementary CLIL lesson or a separate CLIL module. The most recurrent mode of CLIL integration in the classroom is teacher teamwork, i.e. when a subject teacher works together with a foreign-language teacher. The cases where either subject teachers integrate a foreign language or foreign-language teachers integrate a subject in their classes are of nearly equal occurrence (see Table 1).

Table 1: Modes of CLIL in schools.

\begin{tabular}{|c|c|}
\hline Mode & Relative frequency \\
\hline Team work between subject and foreign-language teachers & $57.4 \%$ \\
\hline Subject teacher integrating foreign language & $22 \%$ \\
\hline Foreign-language teacher integrating subject & $20.6 \%$ \\
\hline
\end{tabular}

As was noted in the Introduction, no comparable data concerning the number of schools implementing CLIL when the English language is integrated with a content subject were available. However, the results of the present research demonstrated that English is the most popular language used for teaching CLIL in Lithuania. Having in mind the status, role and popularity of the English language in the world, this finding cannot be considered unexpected. However, the fact that the Russian language is the second most popular language used for teaching CLIL in Lithuania can encourage debates about its relevance in the context of the geopolitical situation of Lithuania. However, the principals of schools surveyed explain its popularity by the fact that older subject teachers feel more confident teaching CLIL in Russian rather than other languages due to the education they received in the times of the former USSR. The other two languages used as CLIL languages in Lithuania are German and French (see Table 2). In the case of German, the coteaching mode prevails, as very few subject teachers can teach in German. The situation is different with French, as in most cases it is integrated into subjects by subject teachers themselves, who received ample training in French within qualification improvement programmes supported by the French government before enrolling in CLIL programmes.

It could be generalized that the situation concerning the choice of languages for teaching CLIL in Lithuania reflects the general situation of foreign language teaching: the foreign language taught in school as the first foreign language is used in most cases for content and language integrated teaching.

Table 2: CLIL languages in schools.

\begin{tabular}{|c|c|}
\hline CLIL languages & Number of schools \\
\hline English & 110 \\
\hline Russian & 39 \\
\hline German & 32 \\
\hline French & 14 \\
\hline
\end{tabular}

In terms of subjects that are integrated with a foreign language in schools, three fields of subjects can be distinguished: science, IT and arts. The most recurrently integrated subjects in the schools surveyed are geography, history, mathematics, IT, technologies, art, and music (for descriptive data, see Table 3).

Table 3: The most popular CLIL subjects.

\begin{tabular}{|c|c|}
\hline Subject & Number of schools \\
\hline Geography & 45 \\
\hline History & 41 \\
\hline Mathematics & 34 \\
\hline Information Technologies & 30 \\
\hline Technologies & 27 \\
\hline Art & 26 \\
\hline
\end{tabular}




\begin{tabular}{|c|c|}
\hline Music & 26 \\
\hline
\end{tabular}

The analysis of CLIL coverage over different grades in schools indicated that, although CLIL is offered in all grades at secondary schools (from 1 to 12), we can observe an increasing recurrence up to grades 7-8 where CLIL provision reaches its peak. In grades 9-10 it starts decreasing, and in grades 11-12 descends lower than the level of grades 3-4 (see Figure 2). As can be seen from the results, the first and the last grades are the least favourable for integrating CLIL in the curriculum. It is very probable that CLIL is less frequently provided in the initial grades (1-2) because school students are not considered to have sufficient foreign language skills to study content subjects integrated with a foreign language. On the other hand, the final grades (11-12) might be considered as unfavourable for CLIL classes due to the increased student workload and pressure preparing for the final examinations. Some respondents mention that CLIL is impossible due to deficient learner skills in both a subject and a foreign language. Some students face difficulties in learning a subject in their mother tongue, so learning a subject in a foreign or through a foreign language would have a negative effect on their subject achievement and motivation to study. Other respondents emphasise the importance of the Lithuanian language in the light of insufficient Lithuanian language literacy achievements. ${ }^{5}$

Figure 2: Distribution of CLIL classes across secondary education grades.

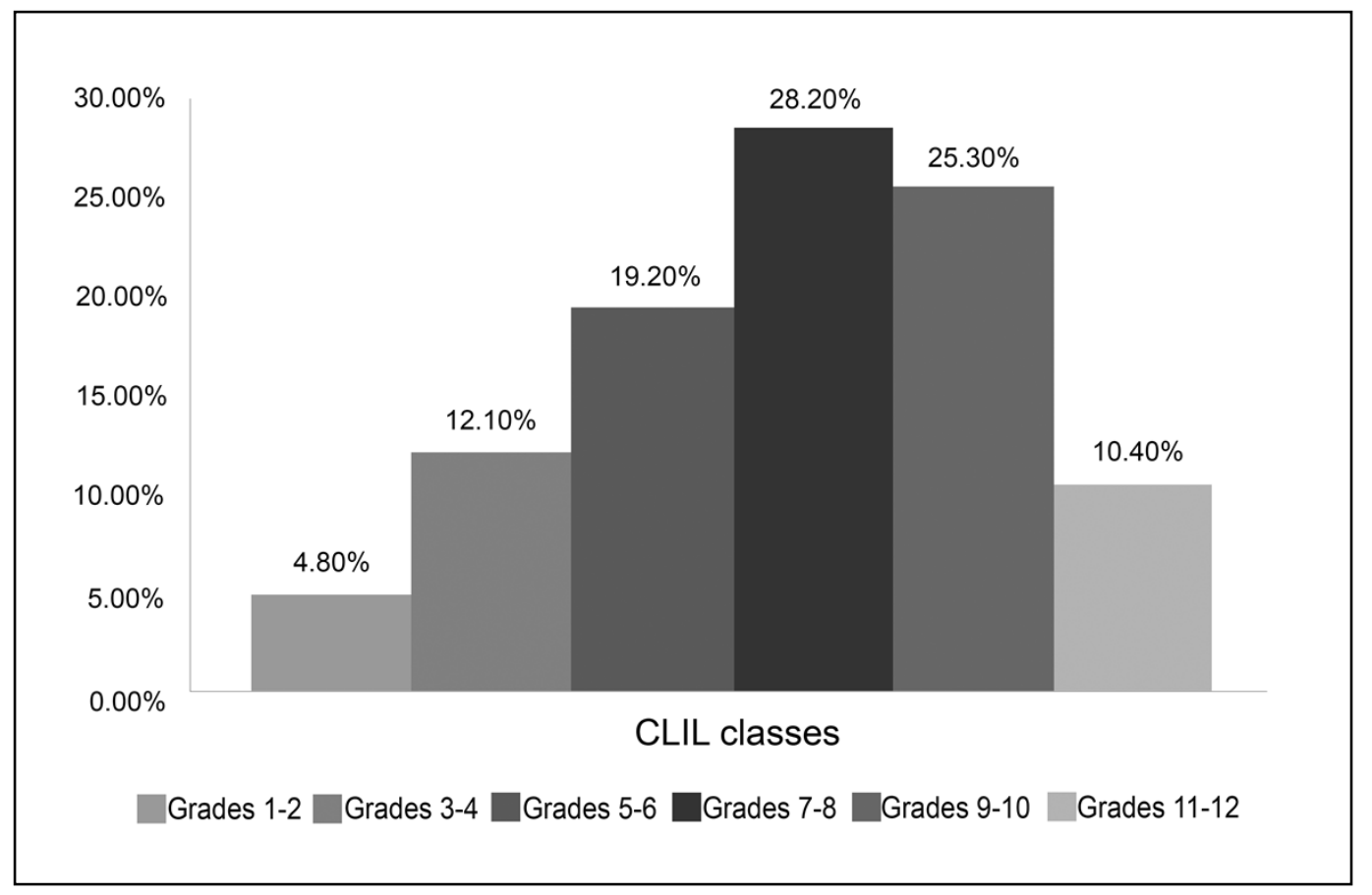

Analysing the current situation of CLIL implementation, we considered it important to determine the proponents of CLIL in schools. According to schools administrators, they are the initiators of CLIL in their schools because integrated learning is recommended as a part of the curriculum by the Ministry of Education and Science of the Republic of Lithuania. Foreign-language teachers are the second most enthusiastic proponents of CLIL. Subject teachers and external initiators such as parents and social partners comprise the last third of all CLIL initiators (see Table 4).

Table 4: Initiators of CLIL.

\begin{tabular}{|c|c|}
\hline Initiator & Relative frequency \\
\hline Administration of schools & $37 \%$ \\
\hline
\end{tabular}


ERL Journal Volume 2019-1(1). Boosting the Educational Experiencing of Language

\begin{tabular}{|c|c|}
\hline Foreign-language teachers & $32 \%$ \\
\hline Subject teachers & $17 \%$ \\
\hline External initiators & $14 \%$ \\
\hline
\end{tabular}

To sum up the results of the analysis of the current situation of CLIL implementation in Lithuanian secondary schools, it should be pointed out that CLIL to a certain degree is accessible to students of nearly half of the schools surveyed. Students studying in grades 5-10 are most likely to have a possibility of CLIL in their curriculum. The most frequently occurring form of CLIL is its integration into a foreign language or content subject classes when two teachers, i.e. a teacher of a foreign language and a teacher of a content subject are working together as a team. The most popular languages for teaching CLIL are English and Russian and the most popular CLIL subjects are geography, history, mathematics and IT.

\section{The administration's perspective on CLIL}

One of the objectives of the present research was to identify the administration's perspective on CLIL by exploring school principals' awareness of CLIL and its principles, the need for official regulation of CLIL implementation, the need for CLIL teacher-competence development, etc. It was also considered important to determine differences, if any, between the approaches towards CLIL of school principals who implement CLIL in their schools with those who do not.

The results of the analysis demonstrated that there is a direct dependence between CLIL implementation and school principals' awareness of its importance, i.e. two thirds of the school principals from schools with CLIL highlighted the importance of CLIL in the teaching process, whereas only one third of the principals from schools without CLIL were inclined to consider CLIL as a necessary approach in the learning / teaching process. As for the need for more information concerning its implementation, the majority of those who have CLIL in their schools claimed to be aware of CLIL principals and organization, and they contributed to awareness in their communities; however the majority of those who did not have CLIL in their schools claimed to be insufficiently aware of CLIL principles and organization and did not contribute much to the awareness in their community (see Table 5).

School principals from schools with CLIL tend to see the value of CLIL and the necessity of disseminating the idea of CLIL by sharing their good practices, modules and materials developed; encouraging teacher collaboration and promoting the CLIL-school network; whereas principals of schools without CLIL are less enthusiastic about CLIL in Lithuanian schools, doubting if bilingual education in Lithuania is necessary in general.

The lack of enthusiasm might be caused by the absence of awareness of CLIL value and leads to the principle if I don't see the benefits of CLIL, my community and I don't need it. If this proves to be the case, there is a strong chance that the education of school administrators in terms of CLIL and its principles would improve the overall situation of CLIL in schools.

Table 5: Importance and awareness of CLIL in secondary education from the perspective of school principals.

\begin{tabular}{|c|c|c|}
\hline $\begin{array}{c}\text { In schools with CLIL } \\
\text { In schools without CLIL }\end{array}$ & $30.9 \%$ \\
\hline $\begin{array}{c}\text { School principals consider CLIL as necessary in secondary } \\
\text { education }\end{array}$ & $70.7 \%$ & $34.6 \%$ \\
\hline $\begin{array}{c}\text { School principals claim to be well-aware of CLIL principles } \\
\text { and organization }\end{array}$ & $82.7 \%$ & $22 \%$ \\
\hline
\end{tabular}

One of the possible demotivating factors for implementing CLIL in schools - the absence of clearly defined procedures and regulations for its introduction and implementation - proved to be relevant. Both the administrators of schools with CLIL and without CLIL emphasized the need for an official document regulating CLIL implementation. The adoption of a law or regulations for implementing CLIL would 
therefore stimulate the process of CLIL dissemination in schools. A number of school principals claim that a recommended curriculum with a clearly defined CLIL concept, principles, evaluation and organisational procedures in Lithuanian secondary schools under currently existing legal regulations would be helpful both in introducing and sustaining CLIL. Whereas now, very few see the possibility of applying CLIL on a regular basis because of difficulties in financing extra classes and the lack of suitable teaching materials or CLIL textbooks that adhere to the current curriculum.

Another possible complication in CLIL implementation is the shortage of qualified CLIL teachers. The results of the survey showed that half of the principals of schools with CLIL are satisfied with the qualifications of their CLIL teachers, and only a negligible number of principals in schools without CLIL considered their teachers' qualification to teach CLIL as sufficient. Hence, the situation of CLIL: schools that have qualified teachers are more inclined to adopt CLIL and those that do not have qualified teachers are reluctant to start teaching CLIL. On the other hand, the lack of qualified CLIL teachers in schools without CLIL might be predetermined by the fact that only half of the principals of schools without CLIL promote their teachers' professional development, whereas in schools with CLIL teachers' professional development is promoted by the majority of principals.

Considering the fact that the present teacher-training system offers study programmes for students majoring in only one subject, school principals consider it essential to provide additional foreign-language and CLIL methodology training. The majority of principals believe that CLIL classes are more likely to be given by younger-generation teachers, who have adequate foreign language skills (B2 according to CEFR Council of Europe 2001, 2018); however with the dominance of older-generation teachers in present-day schools, the co-teaching model remains prevalent and requires further investment to boost the foreignlanguage skills of subject teachers.

Table 6: Teacher qualification and its promotion in secondary schools.

\begin{tabular}{|c|c|c|}
\hline & In schools with CLIL & In schools without CLIL \\
\hline $\begin{array}{l}\text { School principals consider their teachers adequately } \\
\text { qualified }\end{array}$ & $56.4 \%$ & $8.9 \%$ \\
\hline $\begin{array}{c}\text { School principals promote their teachers' professional } \\
\text { development }\end{array}$ & $83.5 \%$ & $51.8 \%$ \\
\hline
\end{tabular}

As can be seen in Table 6, there is a significant difference between schools with CLIL and schools without CLIL as regards the principals' evaluation of their teachers' qualification and the promotion of teachers' professional development for CLIL teaching. However, among principals of both categories, the inclination to finance the development of linguistic competences for their subject teachers is not significantly different (see Table 7). This can be accounted for by the lack of freedom in terms of finance management, as well as by the available resources, which directly depend on the number of students in the school. The fewer the students, the smaller the funds assigned to the school, thus diminishing the possibilities for teacher qualification improvement.

Table 7: School principals' inclination towards investment in teachers' professional development and remuneration.

\begin{tabular}{|c|c|c|}
\hline & In schools with CLIL & In schools without CLIL \\
\hline $\begin{array}{c}\text { School principals are inclined to finance their subject } \\
\text { teachers' linguistic competences development }\end{array}$ & $62.4 \%$ & $42.9 \%$ \\
\hline $\begin{array}{c}\text { School principals find it possible to fund co-teaching } \\
\text { (subject and foreign language teachers) }\end{array}$ & $45.9 \%$ & $23.2 \%$ \\
\hline
\end{tabular}

The implementation of CLIL as a specific educational approach incurs extra expenses and demands additional investment not only in the professional development of teachers, but also in their remuneration. In that respect, principals of schools with CLIL appeared to be more flexible in comparison to those of schools without CLIL - principals of schools with CLIL were twice as much inclined to remunerate coteaching (subject and foreign language teachers) than were principals of schools without CLIL (see Table 7). 
School principals claim that CLIL meets severe limitations because of the current school financing policy (a student voucher system), which results in few possibilities to fund co-teaching or give teachers a bonus for CLIL classes whose preparation is more time-consuming. Thus, in order to ensure proper and continued CLIL implementation, school principals need clearly defined mechanisms and sources of financing approved by educational authorities.

As for principals' general inclination towards introducing CLIL classes into their school curriculum, a similar tendency was revealed - principals of schools with CLIL were more than twice as inclined to introduce CLIL than were principals of schools without CLIL. This general tendency was not affected by an additional variable - the availability of competent and willing CLIL teachers. The availability of competent and enthusiastic teachers increased principals' general inclination towards the introduction of CLIL classes; however, the difference in proportion between increase among principals of schools with CLIL and without CLIL was insignificant (see Table 8).

Table 8: School principals' inclination towards introducing CLIL classes into the school curriculum.

\begin{tabular}{|c|c|c|}
\hline & In schools with CLIL & In schools without CLIL \\
\hline $\begin{array}{c}\text { Principals are inclined towards introducing CLIL } \\
\text { classes into the school curriculum }\end{array}$ & $36.9 \%$ & $14.3 \%$ \\
\hline $\begin{array}{c}\text { Principals are inclined towards introducing CLIL } \\
\text { classes provided there are competent and willing } \\
\text { teachers to teach CLIL }\end{array}$ & $54.9 \%$ & $29.7 \%$ \\
\hline
\end{tabular}

With the on-going reforms in the Lithuanian education system, school communities lack a clear vision and strategies for education in general. There is encouragement to apply the CLIL approach in schools, but some school principals expect answers to such questions as: is bilingual education important to the community? If yes, then which languages should be promoted? Which student groups should be targeted? How should assessment be carried out, and how can the continuation of CLIL programmes in different school types be ensured?

School principals admit that the role of the administration in the adoption of the CLIL approach is essential, but in successful implementation of CLIL the key actor is a teacher who is motivated, professional, creative, open to challenges, willing to share good practices and who has life-long learning competence. According to some school principals, the provision of such teachers, and consequently quality CLIL education, is possible only if an essential reform of the teacher training system is undertaken.

It maybe concluded that the opinion of school administrators plays a crucial role in the life of school communities. As correctly maintained by Mehisto (2014: 44), "the principal is logically first and foremost an instructional / curriculum leader". Therefore, principals make important decisions which, at times, are not necessarily directly dependent on external factors such as the availability of funds, human resources or legal regulations but rather on intrinsic factors such as educational, cultural, political values or personal beliefs and convictions. The definition, interpretation and implementation of CLIL therefore largely depend on the local personal initiatives of school community members.

\section{Conclusions}

Analysis of the current state of CLIL education in Lithuanian secondary schools from the schooladministration perspective demonstrated that nearly half of the surveyed schools apply CLIL - in most cases initiated by the school administration or foreign-language teachers. In the majority of schools, only from 1 to 3 classes of students have the possibility of studying under the CLIL approach. Although CLIL is taught at all levels of secondary education, it is done most extensively in grades 7-10. The prevailing model of CLIL provision is co-teaching in either a foreign-language class or a subject class. The most popular subjects integrated with a foreign language are geography, history, mathematics and IT. The English language is the predominant CLIL language; the second most popular CLIL language is Russian.

From the school administrators' perspective, more effective application of CLIL in Lithuanian secondaryschool education would be facilitated by: 
- adoption of a national policy and / or a legal document regulating CLIL implementation;

- inclusion of CLIL in the curriculum;

- provision of methodology and recommendations for the CLIL co-teaching model;

- provision of professional development for CLIL teachers;

- definition of sources of funding and a payment system for CLIL teaching and co-teaching;

- raising CLIL awareness and benefits to school communities;

- closer collaboration between schools with CLIL and schools without CLIL in sharing good practices.

Further research on the perspectives of other stakeholders as regards CLIL in Lithuanian secondary education would contribute to the validity of the present findings and would help to better assess the current situation.

\section{References}

Andziulienè, L., Kelly, K., Krikštaponis, A. \& Vilkancienė, L. (2007). Integruotas dalyko ir užsienio kalbos mokymas. Vilnius: SCA. Reprint.

Andziulienè, L. (2016). Istorijos ir anglu kalbos studiju programos metavertinimas transformuojamojo ugdymo aspektu. Pedagogika, 123 (3), 104-119. http://dx.doi.org/10.15823/p.2016.36 (Accessed on 12 December 2018).

Ball, P., Kelly, K. \& Clegg, J. (2015). Putting CLIL into practice. Oxford, UK: Oxford University Press.

Bijeikienè, V. \& Pundziuvienè, D. (2015). IDKM diegimas Lietuvos bendrojo lavinimo mokyklose: atvejo analizè, Coactivity / Santalka, 23 (1), 1-13. https:// dx.doi.org/10.3846/cpe.2015.252 (Accessed on 12 December 2018).

Codó, E. \& Patiño-Santos, A. (2017). CLIL, unequal working conditions and neoliberal subjectivities in a state secondary school. Language Policy, 17 (4), 479-499. https:// dx.doi.org/10.1007/s10993-017-9451-5 (Accessed on 20 January 2019).

Council of Europe. (2018). Common European Framework of Reference for Languages: Learning, Teaching, Assessment. Companion Volume with New Descriptors. https://rm.coe.int/cefr-companion-volume-with-newdescriptors-2018/1680787989. Accessed on 30 January 2019.

Council of Europe. (2001). Common European Framework of Reference for Languages: Learning, Teaching, Assessment. https://rm.coe.int/1680459f97. Accessed on 6 November 2018.

Coyle, D., Hood, P. \& Marsh, D. (2010). CLIL: Content and Language Integrated Learning. Cambridge, UK: Cambridge University Press.

Czura, A. \& Papaja, K. (2013). Curricular models of CLIL education in Poland. International Journal of Bilingual Education and Bilingualism, 16 (3) ,321-333, https:// dx.doi.org/10.1080/13670050.2013.777388 (Accessed on 10 January 2019).

Dalton-Puffer, C. (2011). Content-and-Language Integrated Learning: from practice to principles? Annual Review of Applied Linguistics, 31, 182-204. https:// dx.doi.org/ 10.1017/S0267190511000092 (Accessed on 20 January 2019).

Dalyko ir užsienio kalbos integruoto mokymo(si) gairès. Projektas. 2010. „Švietimo naujienos“, no. 7 (296). Accessed on 19 November 2018. http://www.smm.lt/uploads/documents/Archyvas/It_kalbos_politika/IDKM_projektas.pdf.

Doiz, A. \& Lasagabaster, D. (2017). Management teams and teaching staff: do they share the same beliefs about obligatory CLIL programmes and the use of the L1? Language and Education, 31 (2), 93-109. https:// dx.doi.org/10.1080/09500782.2017.1290102 (Accessed on 20 January 2019).

European Commission/EACEA/Eurydice. (2017). Key data on teaching languages at school in Europe. Luxembourg: Publications Office of the European Union.

European Commission. (2008). Multilingualism: An Asset for Europe and a Shared Commitment. Communication of the European Commission.

European Commission/EACEA/Eurydice. (2006). Key data on teaching languages at school in Europe. Luxembourg: Publications Office of the European Union.

European Commission. (2003). Promoting Language Learning and Linguistic Diversity: An Action Plan 2004-2006.

European Commission. (1995). White Paper on Education and Training. Teaching and Learning: towards the Learning Society.

García, O. (2009). Bilingual Education in the 21st Century. Hoboken, NJ: Wiley-Blackwell.

Hüttner, J., Dalton-Puffer, C. \& Smit, U. (2013). The power of beliefs: lay theories and their influence on the implementation of CLIL programmes. International Journal of Bilingual Education and Bilingualism, 3, 267-284. https:// dx.doi.org/10.1080/13670050.2013.777385 (Accessed on January 15 2019).

Lancaster, N. K. (2016). Stakeholder Perspectives on CLIL in a Monolingual Context. English Language Teaching, 9 (2), 148-177. https:// dx.doi.org/10.2167/beb466.0 (Accessed on 20 January 2019). 
Lo, Y. Y. (2014). A glimpse into the effectiveness into the effectiveness of L2-content cross-curricular collaboration in content-based instruction programmes. International Journal of Bilingual Education \& Bilingualism, 18 (4), $443-462$. https:// dx.doi.org/10.1080/13670050.2014.916654 (Accessed on 10 October 2018).

Mehisto, P. \& Asser, H. (2007). Stakeholder Perspectives: CLIL Programme Management in Estonia. International Journal of Bilingual Education and Bilingualism, 10 (5), 683-701. https://dx.doi.org/10.2167/beb466.0 (Accessed on 20 January 2019).

Mehisto, P., Marsh, D. \& Frigols, M. J. (2012). Uncovering CLIL: Content and language integrated learning in bilingual and multilingual education. Oxford, UK: Macmillan. Reprint.

Mehisto, P. \& Genesee, F. (2015). Building Bilingual Education Systems. Forces, Mechanisms and Counterweights. Cambridge: Cambridge University Press.

Mehisto, P. (2014). Excellence in Bilingual Education. A Guide for School Principals. Cambridge: Cambridge University Press. Reprint.

Pérez Cañado, M. L. (2018). This Issue. Theory into Practice, 57 (3), 163-165. https:// dx.doi.org/10.1080/00405841.2018.1496758 (Accessed on 20 January 2019).

Pérez-Cañado, M. L. (2012). CLIL Research in Europe: past, present, and future. International Journal of Bilingual Education and Bilingualism, 15 (3), 315-341. https:// dx.doi.org/10.1080/13670050.2011.630064 (Accessed on 20 January 2019).

Pérez, D., Fields, D. L. \& Marsh, D. (2018). Innovations and Challenges: Conceptualizing CLIL Practice. Theory and Practice, 57 (3), 177-184. https:// dx.doi.org/10.1080/00405841.2018.1484037 (Accessed on 20 January 2019).

Pisa 2015 Results in Focus. (2016). OECD.

Romanowski, P. (2018). CLIL Models in Polish Lower Secondary Schools. Kwartalnik Neofilologiczny, 65 (4), $592-605$. https:// dx.doi.org/10.24425/kn.2018.125006 (Accessed on 20 January 2019).

Smala, S. (2014). Sole Fighter Mentality: stakeholder agency in CLIL programmes in Queensland. The Language Learning Journal, 42 (2), 195-208. https://dx.doi.org/10.1080/09571736.2014.889510 (Accessed on 20 January 2019).

Soler, D., González-Davies, M. \& Iñesta, A. (2017). What Makes CLIL Leadership Effective? A Case Study. ELT Journal, 71 (4), 478-490. https://dx.doi.org/10.1093/elt/ccw093 (Accessed on 20 January 2019).

Sylvén, L. K., \& Thompson, A. S. (2015). Language learning motivation and CLIL. Journal of Immersion \& Content-Based Language Education, 3 (1), 28-50. (Accessed on 20 January 2019).

Standard for Bilingual Education. (2012). European Platform - internationalising education. Retrieved from: https://www.nuffic.nl/en/subjects/education-in-the-netherlands/.

http://www.raosoft.com. Accessed on 30 January 2017.

http://svis.emokykla.It. Accessed on 30 January 2017. 